\title{
Penerapan Fatwa DSN MUI No. 23 Tahun 2020 Terhadap Efisiensi Penyaluran ZIS Perspektif Fiqh Al-Aulawiyah di Lazismu Pamekasan
}

\author{
Sitti Masri'ah Hadi' ${ }^{1}$, Alan Su'ud Ma'adi ${ }^{2}$ \\ 1,2Universitas Trunojoyo Madura, Indonesia \\ Email konfirmasi: masriahhadi1@gmail.com
}

\begin{abstract}
ABSTRAK
Penelitian ini bertujuan untuk mengetahui bagaimana penerapan fatwa MUI No. 23 Tahun 2020 terhadap efisiensi penyaluran zakat infaq dan shadaqah perspektif fiqh al aulawiyah Di LAZISMU Pamekasan. Covid-19 berdampak signifikan di berbagai sektor di Indonesia, utamanya pada masyarakat sehingga perlu adanya saluran bantuan demi percepatan pemulihan ekonomi masyarakat. Kabupaten Pamekasan merupakan salah satu daerah yang terkena dampak pandemi dalam sektor ekonomi, pendidikan, sosial dan kesehatan. maka dengan banyaknya masyarakat yang terdampak pandemi harus ada skala prioritas dalam pemberian bantuan khusunya oleh lembaga amil zakat sebagai lembaga yang bergerak dalam bidang kemanusiaan. Penelitian ini fokus terhadap penerapan Fatwa MUI No. 23 Tahun 2020 serta pengaruh penerapan fatwa tersebut terhadap efisiensi penyaluran zakat infaq dan shadaqah berdasarkan figh al aulawiyah atau fiqh skala prioritas. Metode yang digunakan adalah metode field risearch (studi lapangan) yakni penulis turun langsung pada tempat yang akan diteliti untuk memperoleh data yang dibutuhkan. Hasil penelitian ini menunjukkan bahwa penerapan dari fatwa MUI tersebut sudah terlaksana dan dalam penyaluran dana ZIS yang diprioritaskan adalah masyarakat perkotaan dikarenakan mereka lebih merasakan dampak nyata dari Covid-19. Masyarakat perkotaan yang penulis maksud adalah masyarakat yang notabenesnya tidak memiliki lahan pertanian serta mata pencahariannya bergantung pada pendapatan keseharian misalnya pedagang kaki lima, tukang becak, dan semacamnya. Sehingga dengan diterapkannya fatwa MUI tersebut sedikit banyak dapat membantu meringankan beban masyarakat terdampak pandemi.
\end{abstract}

Kata kunci: Pandemi Covid-19; Fatwa MUI; Penyaluran ZIS, Fiqh Al Aulawiyah.

\section{Pendahuluan}

Sejak tahun 2020 Indonesia mengalami masa pandemi yang disebabkan menyebarnya wabah corona virus disiase 2019 atau biasa dikenal dengan covid 19. Covid 19 merupakan penyakit yang disebabkan oleh jenis virus baru Sars-Cov-2 yang dapat menular dari manusia satu ke manusia lainnya melalui kontak yang erat dan droplet yakni percikan cairan pada saat bersin dan batuk, namun tidak menular melalui udar (Ilham, Idris, \& Muttaqin, 2021, p. 10). Masa pandemi ini membuat indonesia mengalami banyak perubahan, baik dari sektor ekonomi, sektor pendidikan, sektor sosial, dan sektor kesehatan. Oleh karena itu pemerintah harus membuat strategi untuk mengurangi dampak yang terjadi sehingga tidak mengalami 
kerugian yang besar ataupun jika mengalami kerugian dapat ditutupi dengan strategi yang diterapkan.

Sektor ekonomi merupakan salah satu sektor yang banyak mengalami perubahan akibat adanya pandemi covid 19. Diantara beberapa dampak yang terjadi pada sektor ekonomi adalah terjadinya PHK besar besaran, berdasarkan hasil data yang didapat yaitu $\geq 1,5$ juta pekerja dirumahkan dan di PHK dengan presentase 90\% pekerja dirumahkan dan $10 \%$ pekera di PHK. Terjadi penurunan PMI Manufacturing Indonesia yang mencapai $45,3 \%$ pada maret 2020. Terjadinya penurunan impor sebesar 3,7\% pada triwulan 1. Terjadinya inflasi yang telah mencapai pada angka 2,96\% year on year yang telah disumbangkan dari harga emas dan komoditas pangan pada maret 2020. Terjadinya keterbatalan penerbangan yang mengakibatkan pendapatan dalam sektor penerbangan menjadi turun sehingga menyebabkan kerugian, kerugian yang dirasakan mencapai 207 miliar yang disebabkan batalnya penerbangan sebanyak 12.703 pada 15 bandara pada bulan januri-maret 2020. Pada 6000 hotel telah terjadi penurunan penempatan (okupansi) hingga mencapai 50\%, hal tersebut mengakibatkan kehilangan devisa pariwisata.

PHK adalah salah satu dampak dari adanya pandemi yang paling nyata dalam sektor ekonomi, karena hal itu bersentuhan langsung dengan pendapatan perorangan. Terdapat 114.340 perusahaan yang telah merumahkan dan melakukan PHK terhadap tenaga kerja dengan total pekerja sebanyak 1.943 .916 orang yang terkena. Hal itu tentu sangat mempengaruhi pada bertambahnya tingkat kemiskinan. Berdasarkan perkiraan dari Bank Dunia jumlah orang yang hidup dalam kemiskinan ekstrim akan meningkat hingga 922 juta di seluruh dunia, dan apabila indonesia tidak melakukan pencegahan yang tepat dalam menangani pandemi covid 19 ini, maka pertumbuhan ekonomi di indonesia akan tertekan, menurut menteri keuangan indonesia penekanan terhadap pertumbuhan ekonomi di prediksi mencapai 2,5\%-0\% (Yamali \& Putri, 2020).

Merosotnya pertumbuhan ekonomi tentu sangat berpengaruh pada aktivitas kehidupan masyarakat, karena ekonomi merupakan faktor penting dalam menunjang kehidupan. Oleh karena itu pemerintah dituntut untuk menjaga stabilitas perekonomian yang ada. Selain berpengaruh pada aktivitas kehidupan masyarakat, pertumbuhan ekonomi merupakan faktor yang penting dalam mendukung pertumbuhan nasional suatu negara.

Selain dalam sektor ekonomi, pandemi covid 19 juga sangat berdampak pada sektor-sektor yang lain, seperti halnya sektor pendidikan, sektor kesehatan serta sektor sosial. Dalam sektor pendidikan terdapat perubahan strategi pembelajaran, yang mana sebelum adanya pandemi, pembelajaran dilakukan dengan tatap muka secara langsung, namun karena adanya pandemi maka pembelajaran dilakukan secara daring mengacu pada Surat Edaran Mendikbud Nomor 3 Tahun 2020 tentang Pencegahan Covid-19 pada Satuan Pendidikan, dan Nomor 
36962/MPK.A/HK/2020, sehingga hal tersebut tentu sangat berpengaruh pada efektivitas kegiatan belajar mengajar dan juga terhadap pemahaman yang akan diperoleh siswa ataupun mahasiswa (Samudera, 2020).

Dalam sektor kesehatan terdapat banyaknya angka kematian yang disebabkan ganasnya serangan virus corona, angka kematian tersebut mencapai lebih 40 ribu orang pada akhir maret 2021 (Aeni, 2021). Untuk sektor sosial perubahan yang dialami berkaitan dengan berubahnya aktivitas sosial yang disebabkan aturan pemerintah terhadap pembatasan aktivitas sosial serta pembatasan mobilitas yang mana masyarakat harus menerapkan physical distancing seperti jaga jarak, menghindari kerumunan dan berdiam diri dirumah.

Dalam mengatasi pandemi ini pemerintah indonesia membuat beberapa upaya demi memutus mata rantai covid 19, diantaranya dengan menerapkan lockdown, memberlakukan PSBB (Pembatasan Sosial Berskala Besar) yang didasarkan pada PP No. 21 Tahun 2020, namun di awal 2021 kemudian diganti menjadi PPKM (Pemberlakuan Pembatasan Kegiatan Masyarakat), work from home (WFH) (Hanafi \& dkk, 2020, p. 27), memberikan vaksinasi gratis, serta memberikan BLT (Bantuan Langsung Tunai). Sejalan dengan pemerintah, dalam penanganan wabah covid 19 Majelis Ulama Indonesia (MUI) selaku pemberi fatwa yang akan menjadi pedoman bagi masyarakat muslim Indonesia, MUI mengeluarkan kebijakan sebagai bentuk ikhtiar dalam menganggulangi wabah covid 19.

Kebijakan tersebut tertuang dalam Fatwa MUI No. 23 Tahun 2020 yang berisi tentang pemanfaatan harta zakat infaq dan shadaqah untuk penanggulangan covid 19 dan dampaknya. Mengingat masyarakat indonesia mayoritas beragama islam maka zakat infaq dan shadaqah termasuk penunjang negara dalam mewujudkan masyarakat yang sejahtera serta membantu pembangunan nasional. Dalam membantu pengumpulan dan pengelolaan dana ZIS dibutuhkan badan atau lembaga yang fokus pada tugas tersebut. Di Indonesia lembaga tersebut biasa dikenal dengan BAZNAS, LAZIZMU, LAZISNU, BMH dan lain-lain.

LAZISMU Pamekasan merupakan salah satu lembaga amil zakat infaq dan shadaqah yang aktif dalam menyalurkan dana ZIS (Zakat Infaq Shadaqah) untuk kemanusiaan serta turut berperan dalam penggulangan wabah covid 19 khususnya di Kabupaten Pamekasan. Mengingat dampak dari covid 19 melibatkan banyak sektor, maka ketepatan dalam penyaluran dana zakat infaq dan shadaqah berdasarkan skala prioritas menjadi sangat penting, sehingga dana zakat infaq dan shadaqah tersebut benar-benar bermanfaat dalam membangun kesejahteraan dan sesuai dengan fatwa MUI No. 23 Tahun 2020 .

Berdasarkan uraian di atas, penelitian ini dilakukan dengan tujuan untuk mengetahui penerapan fatwa MUI No. 23 Tahun 2020 di LAZISMU Pamekasan, penyaluran dana zakat, infaq dan shadaqah di LAZISMU Pamekasan selama pandemi, serta pengaruh penerapan fatwa MUI No. 23 terhadap efisiensi penyaluran 
dana zakat, infaq dan shadaqah di LAZISMU Pamekasan perspektif fiqh alaulawiyah.

\section{Metode Penelitian}

Metode penelitian yang peneliti gunakan adalah jenis metode kualitatif dengan menggunakan jenis penelitian lapangan (field research) yaitu suatu penelitian dengan cara terjun langsung ke lokasi penelitian untuk memperoleh data yang berkaitan dengan masalah yang dibahas. Metode pendekatan pada penelitian ini adalah deskriptif kualitatif yakni peneliti mengumpulkan data-data yang berkaitan dengan permasalahan yang diteliti, melalui wawancara, foto dan dokumen.

Jenis data yang digunakan pada penelitian ini ada dua yakni data primer dan data sekunder. Data primer diperoleh langsung dari sumber pertama baik melalui observasi atau wawancara kepada para pihak yang berkaitan dalam hal ini manager dan staff di LAZISMU Pamekasan. Data sekunder adalah data yang diperoleh dari sumber kedua sebagai pelengkap dalam hal ini diperoleh melalui literatur-literatur yang berkaitan dengan penelitian yang diteliti.

Metode analisi data yang dilakukan oleh peneliti melalui 3 tahap yaitu reduksi data, penyajian data kemudian verifikasi atau penarikan kesimpulan. Menurut HB Sutopo, redukasi data adalah bagian dari proses analisis yang mempertegas, memperpendek, membuat fokus, membuang hal-hal yang tidak penting, dan mengatur data sedemikian rupa sehingga simpulan penelitian dapat dilakukan (Sutopo H. B., 2002, p. 92). Data yang sesuai dengan permasalahan penelitian kemudian disajikan dalam bentuk narasi, dan disimpulkan sesuai dengan yang telah tersaji.

\section{Hasil Penelitian Dan Pembahasan}

\section{A. Pandangan Umum Tentang Fatwa MUI No. 23 Tahun 2020 Dan LAZISMU Pamekasan}

Fatwa MUI merupakan salah satu regulasi yang menjadi pedoman umat islam dalam menjalani kehidupan. Selain dari Al-Quran dan Hadist, untuk menjawab persoalan-persoalan kehidupan yang dialami oleh umat islam khususnya di Indonesia MUI (Majelis Ulama Indonesia) hadir dengan fatwa-fatwanya yang menjadi solusi terhadap permasalahan-permasalahan yang dialami oleh umat islam Indonesia.

Hal ini sesuai dengan fungsional fatwa yakni tabyin dan taujih, tabyin yaitu menjelaskan tentang hukum sehingga nanti menjadi regulasi praktis bagi masyarakat yang membutuhkan hukum tersebut, taujih yaitu memberikan petunjuk serta pencerahan kepada masyarakat luas tentang permasalahan agama kontemporer (Wahid, 2016). Berdasarkan fungsi-fungsi yang telah disebutkan meskipun tidak bersifat mengikat layaknya hukum positif fatwa MUI juga bisa menjadi regulasi 
yang membantu permasalahan Negara khususnya dalam kesejateraan masyarakat, seperti contoh dalam penanggulangan wabah pandemi covid 19.

Dalam menyikapi permasalahan pandemi covid 19 pada tanggal 22 Sya'ban 1441 H/ 16 April 2020 MUI mengeluarkan fatwa yakni fatwa MUI No. 23 Tahun 2020 tentang pemanfaatan harta ZIS untuk penanggalungan Covid 19 dan dampaknya. Dengan adanya fatwa tersebut harta yang berasal dari dana zakat, infaq dan shadaqah bisa disalurkan pada masyarakat yang terkena dampak pandemi sehingga bisa sedikit membantu kesulitan yang mereka hadapi khususnya dalam masalah ekonomi.

Zakat adalah bagian dari harta dengan persyaratan tertentu yang diwajibkan allah SWT untuk dikeluarkan dan diberikan kepada orang yang berhak menerimanya (Hafidhuddin, 2002, p. 7). Infaq adalah mengeluarkan sebagian harta atau pendapatan untuk menunaikan kepentingan yang diperintahkan oleh agama bagi orang yang beriman tanpa melihat ada atau tidaknya penghasilan yang dihasilkan dari individu (Novalia, Sumantri, \& Panorma, 2020). Shadaqah adalah pemberian dari seorang muslim secara suka rela tanpa batas waktu dan jumlah dengan niat mengharapkan ridho Allah SWT (Aprilianto \& Widiastuti, 2021).

Berikut isi dari fatwa MUI No. 23 Tahun 2020 (MUI, 2020):

Pertama, berisi tentang ketentuan umum yang menjelaskan tentang istilahistilah yang berkaitan dengan pembahasan dalam fatwa tersebut, istilah-istilah tersebut yaitu:

a. Pemanfaatan adalah pendistribusian harta zakat, infak, dan shadaqah kepada penerima, dan penggunaan harta tersebut secara tepat oleh penerima.

b. Hawalan al-haul adalah masa satu tahun atas kepemilikan harta tertentu sebagai syarat wajib zakat.

c. Penanggulangan wabah COVID-19 dan dampaknya adalah segala ikhtiar yang ditujukan untuk mencegah penyebaran COVID-19, merawat dan menangani korban COVID-19, memperkecil angka kematian, membatasi penularan dan penyebaran penyakit agar wabah tidak meluas ke daerah lain, serta membantu kesulitan umat Islam yang terdampak COVID-19.

d. Aset kelolaan adalah sarana dan/atau prasarana yang diadakan dari harta zakat, infak, dan shadaqah yang berada di dalam pengelolaan pengelola/'amil yang manfaatnya diperuntukkan bagi penerima.

Kedua, berisi tentang ketentuan hukum yakni menjelaskan tentang hukum dari penggunaan harta zakat untuk penanggulangan wabah covid 19 dan dampaknya, berikut penjelasannya:

1. Pemanfaatan harta zakat untuk penanggulangan wabah COVID 19 dan dampaknya,hukumnya boleh dengan dhawabith sebagai berikut:

a. Pendistribusian harta zakat kepada mustahiq secara langsung dengan ketentuan sebagai berikut: 
1. penerima termasuk salah satu golongan (asnaf) zakat, yaitu muslim yang fakir, miskin, amil, muallaf, yang terlilit hutang, riqab, ibnu sabil, dan/atau fi sabilillah;

2. Harta zakat yang didistribusikan boleh dalam bentuk uang tunai, makanan pokok, keperluan pengobatan, modal kerja, dan yang sesuai dengan kebutuhan mustahiq;

3. Pemanfaatan harta zakat boleh bersifat produktif antara lain untuk stimulasi kegiatan sosial ekonomi fakir miskin yang terdampak wabah.

b. Pendistribusian untuk kepentingan kemaslahatan umum, dengan ketentuan sebagai berikut:

1) Penerima manfaat termasuk golongan (asnaf) fi sabilillah.

2) Pemanfaatan dalam bentuk aset kelolaan atau layanan bagi kemaslahatan umum, khususnya kemaslahatan mustahiq, seperti untuk penyediaan alat pelindung diri, disinfektan, dan pengobatan serta kebutuhan relawan yang bertugas melakukan aktifitas kemanusiaan dalam penanggulangan wabah.

2. Zakat mal boleh ditunaikan dan disalurkan lebih cepat (ta'jil alzakah) tanpa harus menunggu satu tahun penuh (Hawalan alhaul), apabila telah mencapai nishab.

3. Zakat fitrah boleh ditunaikan dan disalurkan sejak awal Ramadhan tanpa harus menunggu malam idul fitri.

4. Kebutuhan penanggulangan wabah COVID-19 dan dampaknya yang tidak dapat dipenuhi melalui harta zakat, dapat diperoleh melalui infaq, shadaqah, dan sumbangan halal lainnya.

Ketiga, berisi tentang rekomendasi yakni menjelaskan tentang harapan serta masukan kepada pemerintah, umat islam dan lembaga amil zakat, berikut isinya:

1. Pemerintah wajib mengoptimalkan daya dukung sumber daya untuk penanggulangan wabah COVID-19 dan dampaknya dengan melakukan langkah cepat guna menjamin keselamatan dan kemaslahatan masyarakat.

2. Umat Islam diharapkan menyalurkan zakatnya melalui badan/lembaga amil zakat yang terpercaya agar manfaatnya nyata.

3. Badan/Lembaga Amil Zakat agar menjadikan fatwa ini sebagai pedoman dalam pengelolaan zakat dengan memprioritaskan tasharruf khususnya untuk kemaslahatan mustahiq yang terdampak COVID-19.

4. Umat Islam yang memenuhi syarat wajib zakat dianjurkan untuk segera menunaikan kewajiban zakatnya agar para mustahiq yang terdampak COVID-19 dapat memperoleh haknya.

Fatwa tersebut sangat relevan untuk diterapkan oleh badan/lembaga amil zakat, karena tugas dari badan/lembaga tersebut adalah mengelola dana hasil dari zakat, infaq dan shadqah. Berdasarkan UU No. 23 Tahun 2011 pengelolaan zakat 
terdiri atas kegiatan pengawasan, perencanaan, pengorganisasian dalam proses pengumpulan, pendistribusian serta pendayagunaan zakat, jadi secara garis besar pengelolaan zakat terdiri dari 3 tahap yakni pengawasan, pendistribusian, dan perencanaan (Sabiq \& Amiruddin, 2021).

Indonesia terdapat banyak badan/lembaga yang bertugas mengelola dana zakat, infaq dan shadaqah baik itu dibentuk oleh Negara ataupun dibentuk oleh swasta baik tingkat nasional ataupun regional, yang dibentuk oleh Negara seperti BAZNAS, yang dibentuk oleh swasta seperti LAZISNU, LAZISMU, BMH, dll. Dalam penelitian ini peneliti hanya fokus pada satu lembaga untuk dijadikan obyek penelitian yaitu LAZISMU(Lembaga Amil Zakat Infaq Shadaqah Muhammadiyah) wilayah Pamekasan.

LAZISMU Pamekasan merupakan lembaga nirlaba tingkat nasional yang berkhidmat dalam pemberdayaan masyarakat melalui pendayagunaan secara produktif dana zakat, infaq, wakaf dan dana kedermawanan lainnya baik dari perseorangan, lembaga, perusahaan dan instansi lainnya. Lembaga tersebut didirikan pada tahun 2002 yang ditandai dengan penandatangan deklarasi oleh Prof. Dr. HA. Syafi'i Ma'arif, MA (Buya Syafi'i) dan selanjutnya dikukuhkan oleh Menteri Agama Republik Indonesia sebagai Lembaga Amil Zakat Nasional melalui SK No. 730/2016 (Menggantikan SK Kemenag R.I. No. 457/2002), tujuan dari lembaga tersebut adalah mengoptimalkan pengelolaan ZIS yang amanah, profesional, dan transparan serta dapat meningkatkan kesejahteraan hidup masyarakat melalui pendayagunaan ZIS yang kreatif, inovatif, dan produktif.

Sebagai lembaga yang bergerak dalam bidang kemanusiaan LAZISMU selalu berperan aktif untuk mensejahterakan masyarakat, terutama pada masa pandemi yang merupakan masa-masa sulit khususnya dalam bidang perekenomian. Dengan banyaknya perubahan yang terjadi akibat pandemi, LAZISMU harus tetap eksis untuk menjalankan program-programnya, baik dalam bidang ekonomi, pendidikan ataupun kesehatan. Dengan seperti itu masyarakat akan merasakan dampak nyata dari adanya LAZISMU.

\section{B. Penerapan Fatwa MUI No. 23 Tahun 2020 Di LAZISMU Pamekasan}

Berkaitan dengan penerapan fatwa MUI No. 23 Tahun 2020, berdasarkan hasil wawancara kepada bapak matnin dan bapak khoirul, penerapan fatwa tersebut telah diterapkan oleh LAZISMU melalui beberapa programnya, diantaranya yaitu memberikan disinfektan dan handsanitaizer pada 13 kecamatan yang berada di Pamekasan dengan cara di titipkan di masjid karena masjid merupakan tempat ibadah yang sering didatangi masyarakat, pembagian masker gratis sebanyak 2000 pcs, santunan dhuafa' dan anak yatim sebanyak 260.

Fatwa tersebut diterapkan karena sangat relevan dengan situasi dan kondisi saat ini, serta merupakan hasil ijtihad para ulama yang telah dikaji secara mendalam. 
Dalam menetapkan fatwa MUI melakukan tiga pendekatan yaitu pendekatan nashqath'I yakni bersumber dari Al-Quran dan Hadits, pendekatan qawly dengan mengambil jawaban dari kitab-kitab mu'tabar, dan pendekatan manhajy yakni melalui ijtihad kolektif. Menurut penelitian yang dilakukan oleh Dliya'ul Chaq fatwa MUI No. 23 Tahun 2020 merupakan upaya cepat tanggap dan tepat guna yang berperan jelas dalam menanggulangi bahaya kesulitan hidup yang dialami masyarakat terdampak pandemi, dengan adanya fatwa tersebut kehidupan manusia dan keberlangsungan agama akan tetap terjaga sesuai dengan teori menutup peluang bahaya (sad al-dzariah) dengan tujuan untuk menyelamatkan kehidupan manusia (hifdzun nafs) dan keberlangsungan agama (hifdzun ad-diin) (Chaq, 2020).

Sebagai bentuk kepedulian yang tinggi, dalam menghadapi pandemi covid 19 muhammadiyah membentuk lembaga yang bersifat ad hoc yaitu MCCC (Muhammadiyah Covid 19 Command Center). Lembaga tersebut merupakan lembaga khusus yang dibentuk untuk mengatasi pandemi dengan menyalurkan bantuan pada masyarakat yang terdampak pandemi. Berdasarkan hasil wawancara di LAZISMU Pamekasan yang menjadi gerbang masuknya dana ZIS adalah LAZISMU kemudian dana tersebut di salurkan oleh MCCC, bisa berupa sembako, masker, handsanitaizer, dll.

\section{Penyaluran Dana ZIS Di Masa Pandemi Di LAZISMU Pamekasan}

Berkaitan dengan sistem penyaluran dana ZIS selama masa pandemi. Bentuk penyaluran dana ZIS ada dua yaitu penyaluran dalam bentuk konsumtif dan produktif (Bintania, 2019, p. 47). Berdasarkan hasil wawancara yang telah dilakukan kepada bapak matnin, penyaluran dana ZIS di LAZISMU berbentuk konsumtif yakni sembako serta alat pencegah penularan covid 19 yang berupa handsanitaizer, masker dan disinfektan, dan ada pula yang berbentuk produktif dalam bentuk modal usaha namun itu binaan langsung dari pusat yang dipasrahkan kepada LAZISMU Pamekasan dengan penerima sebanyak 5 mustahiq. Untuk tata cara penyaluran dana ZIS selama masa pandemi dilakukan dengan door to door yakni amil mendatangi rumah penerima bantuan, hal ini dilakukan untuk menghindari kerumunan dan mentaati anjuran pemerintah.

\section{Pengaruh Penerapan Fatwa MUI No. 23 Terhadap Efisiensi Penyaluran Dana ZIS Perspektif Fiqh Al-Aulawiyah.}

Yusuf Al-Qardhawi berpendapat bahwa fiqh al-Aulawiyah adalah meletakkan segala sesuatu sesuai peringkatnya dengan adil, baik dari segi hukum, nilai ataupun amal, kemudian mendahulukan yang lebih utama berdasarkan pertimbangan syara' yang tepat sehingga perkara yang remeh tidak didahulukan atas perkara yang lebih penting, perkara yang lemah (marjih) mendahului perkara yang rajih. Perkara yang kecil keutamaannya mendahului perkara yang besar 
keutamaannya, serta mendahulukan yang berhak didahulukan dan mengakhirkan yang berhak diakhirkan. Tidak membesarkan perkara yang kecil, tidak memudahkan perkara yang penting. Hendaklah segala sesuatu diletakkan sesuai tempatnya dengan timbangan yang tepat tanpa tindakan yang melampaui batas dan merugikan (Al- Qardhawi, 1998, p. 5).

Melihat banyaknya elemen masyarakat yang terdampak pandemi covid 19, maka sangat penting bagi lembaga amil zakat khususnya LAZISMU untuk mengetahui fiqh al aulawiyah atau skala prioritas dalam penyaluran dana ZIS, sehingga yang benar-benar membutuhkan bantuan dibantu terlebih dahulu. Berdasarkan hasil wawancara yang telah dilakukan, yang menjadi prioritas dalam penyaluran zakat di LAZISMU Pamekasan adalah masyarakat kota yang mata pencahariannya tergantung pada pendapatan sehari-hari, masyarakat kota dijadikan prioritas karena kebanyakan masyarakat kota tidak memiliki lahan pertanian sendiri sehingga untuk kebutuhan pokok mereka harus membeli, sedangkan dengan adanya pandemi tentunya menurunkan ekonomi mereka, apalagi dengan adanya kebijakan stay at home, menjaga jarak dan menghindari kerumunan. Karena hal itu mereka menjadi golongan yang berhak menerima dana ZIS sesuai dengan fatwa MUI No.23 Tahun 2020.

\section{Kesimpulan}

Fatwa MUI NO. 23 Tahun 2020 telah diterapkan oleh LAZISMU Pamekasan melalui beberapa programnya, yakni diantaranya pemberian disinfektan, handsanitaizer, dan masker sebagai pencegahan penularan covid 19, santunan anak yatim dan dhuafa. Penyaluran dana ZIS di prioritaskan pada masyarakat perkotaan yang terdampak pandemi, karena masyarakat perkotaan merupakan masyarakat yang paling merasakan dampak dari adanya pandemi khususnya dalam bidang perekonomian. Penyaluran dana ZIS dilaksanakan secara langsung atau door to door yaitu amil mendatangi langsung rumah penerima bantuan, bantuan yang diberikan ada dalam bentuk konsumtif berupa sembako, handsanitaizer, disinfektan dan masker, dan ada dalam produktif yang berupa modal usaha.

\section{DAFTAR PUSTAKA}

Aeni, N. (2021, Juni). Pandemic COVID 19: Dampak Kesehatan, Ekonomi, dan Sosial. Journal Litbang, 17(1), 18.

Al- Qardhawi, Y. (1998). Fikih Prioritas. Jakarta: Robbani Press.

Aprilianto, E. D., \& Widiastuti, T. (2021, Maret). Pemberdayaan Ekonomi Masyarakat Melalui Pendistribusian Zakat, Infaq dan Sedekah Pada Masa Pandemi COVID 19. Jurnal Ekonomi Syariah Teori dan Terapan, 8(2), 223. 
Bintania, A. (2019). Karakteristik Kebutuhan Mustahiq dan Analisis Prioritas Penyaluran Zakat Oleh BAZNAS Kota Tanjung Pinang. Bintan: STAIN Sultan Abdurrahman Press .

Chaq, M. D. (2020, Juni). Peran Fatwa MUI Dalam Penanggulangan Wabah COVID 19 dan Dampaknya (Studi Fatwa MUI No. 23 Tahun 2020). Jurnal Tafaqquh, $8(1), 138$.

Hafidhuddin, D. (2002). Zakat Dalam Perekonomian Modern. Jakarta: Gema Insani Press.

Hanafi , Y., \& dkk. (2020). Respon Muslim Dalam Kehidupan Sosial Keagamaan Dan Pendidikan. Sidoarjo: Delta Pijar Khatulistiwa.

Ilham, Idris, U., \& Muttaqin, M. Z. (2021). Pandemi Di Ibu Pertiwi: KajianLliteratur "Penanganan Covid 19 Di Indonesia". Aceh: Syiah Kuala Uivercity Press.

MUI. (2020). Pemanfaatan Harta Zakat Infaq Dan Shadaqah Dalam Penanggulangan Wabah COVID 19 Dan Dampaknya.

Novalia, D., Sumantri, R., \& Panorma, M. (2020, Desember). Pengaruh Dana Zakat, Infaq Dan Shadaqah Terhadap Tingkat Kemiskinan Sebagai Variabel Intervening Tahun 2015-2019. Jurnal Al-Iqtishadiyah, 6(2), 137.

Sabiq, A. F., \& Amiruddin, C. (2021, Juli 05). Pendayagunaan Zakat Sesuai Fatwa MUI No. 23 Tahun 2020 Di LAZ Selama Masa Pandemi Covid 19. Jurnal Bimas Islam, 14(1), 171.

Samudera, W. (2020, September). Dampak Pandemi COVID 19 Dalam Pendidikan Di Kota Mataram. Indonesian Journal Of Teacher Education, 1(3), 156.

Sutopo, H. (2002). Metodologi Penelitian Kualitatif. Surakarta: Sebelas Maret Univercity Press.

Sutopo, H. B. (2002). Metodologi Penelitian Kualitatif. Surakarta: Sebelas Maret Univercity Press.

Wahid, S. H. (2016, November). Pola Transformasi Fatwa Ekonomi Syariah DSNMUI Dalam Peraturan Perundang-Undangan Di Indonesia. Journal AHKAM, $4(2), 181$.

Yamali, F. R., \& Putri, R. N. (2020, September). Dampak Pandemi COVID 19 Terhadap Ekonomi Indonesia. Journal of Economics and Business, 4(2), 386. 